\title{
The Political Theater and Theatrical Politics of Andrea Giacinto Cicognini: Il Don Gastone di Moncada (1641)*
}

\author{
Tatiana Korneeva
}

The dramatic production of Giacinto Andrea Cicognini (Florence 1606-1649 Venice) provides a fruitful forum for reflection on the problematics of the political dimension of aesthetics and the aesthetic dimension of politics in the context of Italian Baroque tragedy. Brilliant and productive playwright and librettist, author of some forty-five prose tragedies, commedie regie e politiche, and sacred dramas - as well as of four opera librettos-Cicognini was a man of remarkable theatrical pedigree ${ }^{1}$ as well as a courtier par excellence. From his earliest years, he was closely tied to the Medici court: he was introduced to the court at the age of seven and thereafter came to be employed as a page boy thanks to the special interest his godmother, the grand duchess Christine de Lorraine (1565-1636), took in him. ${ }^{2}$ Thanks to her patronage, Cicognini gradu-

* This essay was written within the framework of the 'Early Modern European Drama and the Cultural Net' ('DramaNet') project, which is funded by the ERC Advanced Grant and located at the Freie Universität Berlin. Special thanks to Amyrose McCue Gill for her valuable editing and translation assistance.

1 Giacinto Andrea's father, Jacopo Cicognini (1577-1633), was a poet, playwright, and member of the Intronati, Instancabili, and Incostanti academies. He may have been a correspondent of Lope de Vega, who wrote a letter in order to convince his Italian fellow-dramatist that blind obedience to the regulations laid down by Aristotle's Poetics was nothing short of foolish. Although Jacopo refers to Lope's advice in the preface to his play Il Trionfo di David (written 1628, printed 1633), his direct acquaintance with Lope has been questioned by Maria Grazia Profeti in her article 'Jacopo Cicognini e Lope de Vega: “attinenze strettissime"?', in id. (ed.), Materiali, variazioni, invenzioni (Florence: Alinea, 1996), pp. 21-31. Legend has it that Jacopo entrusted his son's education to Pier Maria Cecchini, a famous Fritellino of the day. For the most recent account of Cicognini's life and dramatic production, see Flavia Cancedda and Silvia Castelli, Per una bibliografia di Giacinto Andrea Cicognini: Successo teatrale e fortuna editoriale di un drammaturgo del Seicento (Florence: Alinea, 2001), pp. 25-74.

2 Silvia Castelli, 'Il teatro e la sua memoria: la compagnia dell'Arcangelo Raffaello e il "Don Gastone di Moncada" di Giacinto Andrea Cicognini', in Maria Grazia Profeti (ed.), Tradurre, riscrivere, mettere in scena (Florence: Alinea, 1996), pp. 85-94, esp. p. 86; Barbara Maranini, 'Il

(C) TATIANA KORNEEVA, 2016 | DOI: 10.1163/9789004323421_011

This is an open access article distributed under the terms of the CC-BY-NC License. 
ated from the University of Pisa with a degree in law; after his father's death he decided to pursue the career of a writer while earning his living at court as an Ufficial d'Onestà, an officer of the Florentine Office of Decency. By autumn 1646, Cicognini had moved to Venice ${ }^{3}$ and was participating in the cultural activities of the Academia degli Incogniti (The Academy of the Incognitos), 'which functioned as an unofficial seat of political power. ${ }^{4}$ It is not surprising, therefore, that many of his plays' plots involve political situations and consistently feature themes touching on kings, royal ministers, courtiers, attendants at court, and the relationships between a prince and his subjects, and between sovereignty and individual consciousness. Well-known for adapting and reworking Spanish comedias of the Siglo de Oro for the Italian stage, ${ }^{5}$ Cicognini often set his plays

comico nel tragico: I drammi per musica di Giacinto Andrea Cicognini', in Alessandro Lattanzi and Paologiovanni Maione (eds.), Commedia dell'Arte e spettacolo in musica tra Seie Settecento (Naples: Editoriale Scientifica, 2003), pp. 185-212, esp. p. 185.

3 Cicognini's departure from Florence has been attributed to his serious falling-out with some of the Medici's protégés, whom he accused of being panderers. See Anna Maria Crinò, 'Documenti inediti sulla vita e l'opera di Jacopo e Giacinto Andrea Cicognini', Studi secenteschi 2 (1961), 255-286, esp. pp. 258-282.

4 Ellen Rosand, Opera in Seventeenth-Century Venice: The Creation of a Genre (Berkeley: University of California Press, 1991), p. 37. The membership of the academy, which was founded in 1630 by the patrician Giovan Francesco Loredano, consisted of almost all upper-class Venetian intellectuals of any importance as well as a number of non-Venetians. The Incogniti were distinguished from other learned academies by their involvement in most aspects of $L a$ Serenissima's cultural, social, and political life. They were also remarkable for their openness to unorthodox thinking: they opposed cultural conformism and had a distinct predilection for licentious living. Prolific writers of prose, moral and religious tracts, and opera librettos, the members of this powerful academy found their models in the allegorical and satirical literature inspired by Traiano Boccalini's socio-political compendium Ragguagli di Parnasso (Advice from Parnassus, 1612-1614) and expressed their anticonformist views in covert and highly allusive ways. On the Incogniti, see Monica Miato, L'Accademia degli Incogniti di Giovan Francesco Loredan (1630-1661) (Florence: Olschki, 1998); Lucinda Spera, Due biografie per il principe degli Incogniti: Edizione e commento della Vita di Giovan Francesco Loredano di Gaudenzio Brunacci (1662) e di Antonio Lupis (1663) (Bologna: I libri di Emil, 2014); Giorgio Spini, Ricerca dei libertini (Rome: Editrice Universale, 1950). Cicognini was not considered an official member of the academy, and evidence of his relationship to various members of the Incogniti is somewhat speculative. For the connections he may have had with the academy after he settled in Venice, see Nunzia Melcarne, 'Giacinto Andrea Cicognini: Un amico dell'Accademia veneziana degli Incogniti', Aprosiana. Rivista annuale di studi barocchi, n.s., 14 (2006), 34-40.

5 There is a burgeoning literature on Cicognini's role in disseminating Spanish theater in Italy and on the notable bravura with which he transformed his Spanish sources. See, for example, Fausta Antonucci and Lorenzo Bianconi, 'Plotting the Myth of Giasone', in Ellen Rosand 
in the Spanish court-as is, for example, the case with Le gelosie fortunate del principe Rodrigo, Il principe giardiniero, and Il Don Gastone di Moncada. The socio-political environments of other European courts also appear in his oeuvre: Norway in L'Adamira, overo La statua dell'honore, Portugal in L'innocente giustificato, England in La moglie diquattro mariti, Sardegna in Il tradimento per l'onore, and Poland in La vita è un sogno. Sometimes the courts in Cicognini's dramatic works are mythological (Giasone, one of the most enduringly popular and influential operas of the entire Seicento), historical (Gl'amori di Alessandro Magno e di Rossane), exotic (L'Orontea), or even biblical (La Mariene ovvero Il maggior mostro del mondo and Iuditta). His characters include highborn princely protagonists as well as low-ranking commedia dellarte or graciosolike figures, but even the latter belong without exception to aristocratic court culture. The court as a state in miniature, as a centre of decision-making and governance, as a stage for royal and aristocratic representation, and as a social network thus permeates Cicognini's plays at a most profound level. Across the full spectrum of his political plays, we see a playwright exploring different forms of governance and princely conduct, exposing the unavoidable conflicts that arise between ethical behavior and the ragion di stato (reason of state, or national interest), ${ }^{6}$ and engaging with political practice and seventeenthcentury theories of statecraft. ${ }^{7}$

(ed.), Readying Cavalli's Operas for the Stage: Manuscript, Edition, Production (Farnham, Surrey: Ashgate, 2013), pp. 201-227; Guelfo Gobbi, 'Le fonti spagnole del teatro drammatico di G.A. Cicognini: Contributo alla storia delle relazioni tra il teatro italiano e lo spagnolo del Seicento', La biblioteca delle scuole italiane 11, series 3, no. 18 (30 November 1905), 218-222; no. 19 (15 December 1905), 229-231; no. 20 (31 December 1905), 240-242; Nicola Michelassi and Salomé Vuelta García, 'La fortuna del teatro spagnolo a Firenze: Il Don Gastone di Moncada di Giacinto Andrea Cicognini', in Valentina Nider (ed.), Teatri del Mediterraneo: Riscritture e ricodificazioni tra '50o e '6oo (Trento: Editrice Università degli Studi di Trento, 2004), pp. 1942; Nicola Michelassi and Salomé Vuelta García, 'Il teatro spagnolo sulla scena fiorentina del Seicento', Studi secenteschi 45 (2004), 67-137; Diego Símini, 'Alcune opere 'spagnole' di Giacinto Andrea Cicognini fra traduzione, adattamento e creazione', in Paola Andreoli et al. (eds.), Teatro, scena, rappresentazione dal Quattrocento al Settecento: Atti del Convegno internazionale di studi (Lecce, 15-17 maggio 1997) (Galatina: Congedo, 2000), pp. 305-313. Whereas Cicognini scholars have focused either on his role in the diffusion of Spanish Golden Age theater in Italy or on his opera librettos, no attention has been paid thus far to the political dimension of his dramatic works.

6 The bibliography on the ragion di stato or raison d'État is vast. See, for instance, Artemio Enzo Baldini and Anna Maria Battista, 'Il dibattito politico nell'Italia della controriforma: Ragion di Stato, tacitismo, machiavellismo, utopia', Il pensiero politico 30 (1997), 394-439; Michael Stolleis, Stato e ragion di stato nella prima età moderna (Bologna: Il Mulino, 1998), pp. 31-68.

7 It is difficult to establish definitively the parameters of Cicognini's political thought: as was 
What makes Cicognini's dramatic production even more interesting for an investigation of the relationship between politics and aesthetics in Italian Baroque tragedy is his versatility and his remarkable ability to adapt himself to rapidly increasing demand for professional entertainment and to the ravenous theatrical market of the first commercial playhouses and their audiences. Indeed, precisely during his Venetian period (which represents the highpoint of his artistic career), Cicognini brought about the successful 'encounter between tragedy and musical drama' 8 that was to shape the genre of opera over the next several hundred years.

Cicognini's dramatic production, therefore, stands at the intersection of courtly performance, theater produced by learned academies, and entertainment that was only just starting to see professionalization. It thus permits us to explore a fundamental set of questions, beginning with how sovereignty is portrayed in dramas that represent a way station, as it were, in the decisive transition from absolutist court theater to commercial playhouse.

Taking into account the intense engagement of Baroque drama with the socio-political life of the communities in which (and for which) it was written, as well as its function as a harbinger-and then diffusive mechanismof changing political attitudes, we might also seek to uncover the import of Cicognini's tragedies for seventeenth-century audiences. My aim, then, is to explore the significance of this particular playwright's works both within the localized traditions of Italian theater and on a larger European stage.

If we approach Cicognini's political plays as a product of the supply-anddemand forces of the marketplace and with the active influence of his spectators in mind, ${ }^{9}$ we may also be able to learn something about the public's taste in

the case with many of the Incogniti with whom he likely associated, he was too enigmatic a playwright to express openly his stance on political and ideological matters. Nevertheless, certain discernible patterns emerge in his dramatic output. In particular, his interest in politics and in a variety of forms of government suggests that these were central concerns of his writing career and were not exclusively imposed by a need to please either patrons or spectators.

8 Federico Doglio, 'La tragedia barocca', in id. (ed.), Il teatro tragico italiano: Storia e testi del teatro tragico in Italia (Parma: Guanda, 1958), pp. LXXIX-CLXIV, esp. p. CV.

9 Cicognini claimed in the preface 'A i Lettori, \& Spettatori del Drama' to Giasone that he composed it on a whim and with no aim other than to delight: 'Io compongo per mero capriccio; Il mio capriccio non ha altro fine che dilettare; Lapportar diletto appresso di me, non è altro che l'incontrare il genio, \& il gusto di chi ascolta, ò legge.' Giasone: Dramma Musicale del D. Giacinto Andrea Cicognini (Venice: Per il Giuliani. Con Licenza de' Su. e Privilegio, 1649), p. 7. The importance of pleasing a wide audience was also a Leitmotiv of the Incogniti's literary production. 
theater (or, in other words, their aesthetics), and this leads me to the two final questions whose answers I will pursue in these pages. First, in what ways did their performance of sovereignty and the aesthetics of power make Cicognini's plays appeal to different kinds of audiences and, therefore, make them portable to other parts of Italy and across Europe ${ }^{10}$ Second, what was it about his writing for theater that caused his plays to remain phenomenally popular into the eighteenth century?11

\section{A Mixed Tragedy for A Mixed Public: A New Aesthetics of the Tragic Genre}

In order to begin laying bare the relationship between the theatrical stage and the political culture it served, the following analysis will focus on one of Cicognini's political tragedies, Il Don Gastone di Moncada. ${ }^{12}$ Written during his Florentine period (though published in 1658 , posthumously, as were almost all his works), it was staged at the public playhouse Baldracca in Florence in 1641. Il Don Gastone was Cicognini's most often performed play in Florence during the grand duchy of Ferdinand II (1610-1670) and Cosimo III de' Medici (16701723), and it is by far one of his best-travelled and dramatically effective works. ${ }^{13}$ The play's success was so sensational that it even encouraged its author to write

10 For example, on the performance of Cicognini's plays in Russia under Peter the Great (and, in particular, of his Tradimento per l'onore, which was adapted for Russian audiences from a German translation), see Nikolai Tikhonravov, Russkie dramaticheskie proizvedenia 16721725 godov, 2 vols. (Saint Petersburg: Izdanie D.E. Kozancikova, 1874), I, p. 44 and II, p. 80.

11 Symptomatic of the remarkable success, enduring positive reputation, and editorial fortune that Cicognini's works still enjoyed in the eighteenth century is Carlo Goldoni's claim that the Florentine playwright was among his most read and studied dramatic authors: 'Degli autori di commedie che leggevo e rileggevo spesso, il mio preferito era Cicognini. Tale autore fiorentino, poco conosciuto nella repubblica delle lettere, aveva scritto molte commedie d'intreccio, miste di patetico lagrimoso e di comico triviale; eppure vi si trovava molto interesse: egli aveva l'arte di dosare la sospensione e di suscitare diletto grazie allo scioglimento. Mi ci appassionai moltissimo, lo studiai attentamente e, a otto anni, osai abbozzare una commedia'. Goldoni, Memorie, ed. Paolo Bosisio (Milan: Mondadori, 1993), pp. 29-30.

12 All citations of the play are from IL DON $\mid$ GASTONE $\mid$ DI MONCADA $\mid$ Opera scenica, $e$ Morale | DEL DOTTORE | GIACINTO ANDREA | CICOGNINI. | [image of vase with flowers] | IN BOLOGNA, 1682. | Per Gioseffo Longhi. Con lic. de' Sup. Translations of the play and of other sources are mine unless otherwise noted.

13 Michelassi and Vuelta García, 'La fortuna del teatro spagnolo', p. 22. 
a sequel, Il Celio (written in 1645 and first performed in 1646), which had as its protagonist Don Gastone's son Celio. As the preface to Cicognini's first dramma per musica states, ${ }^{14}$ the audience of Il Don Gastone consisted of both privileged and common playgoers: the play was, according to Cicognini, 'enjoyed so much by all' ('all'universale così gradito'). ${ }^{15}$ Subsequently, as Nicola Michelassi and Salomé Vuelta García have pointed out, 'Cicognini's play was performed in Florence in the most diverse theatrical spaces: from religious confraternities to public theaters, from noble academies to private houses. Its success was due to the perfect equilibrium between the subject matter of the work and its scenic efficacy'.16

Il Don Gastone is set in Spain, and takes place during the rule of the corrupt and decadent tyrant Don Pietro Rè d'Aragona. At the outset of the play, Don Gastone of Moncada, who is retired from public court life, lives happily with his loving, faithful wife Donna Violante and devotes his leisure time to hunting. This peaceful existence is disrupted when the king and Don Merichex di Buccoì, a nobleman exiled for having avenged a family dishonor, arrive at Don Gastone's duchy. The host welcomes the newcomers, generously offering Don Merichex his protection and hospitality. In the meantime, the king meets Donna Violante and is immediately so infatuated with her that she becomes the sole object of his attentions. Ignoring the lady's resistance to his advances, the king hatches a plot to pursue her further by inviting the couple and Don Merichex to return with him to the Aragonese court. Although his attempts to seduce Donna Violante continue to be rebuffed, Pietro persists in his determination to possess her: he restores Don Merichex's honor and, in exchange, requires that he exile his new friend Don Gastone and arrange an amorous encounter between the lust-filled king and Donna Violante. Don Merichex,

14 Cicognini, Celio (Florence: Per Luca Francesc. \& Alessandro Logi, 1649), p. 1o: 'Insomma, ti prego a gradire Celio mio se no per altro, almeno perché è figlio del mio Don Gastone, che è stato all'universale così gradito' The preface is dedicated to Leopoldo de' Medici, who commissioned and promoted the production of Florentine libretti that imitated Venetian ones. Cf. Nicola Michelassi, “La "Finta pazza” a Firenze: commedie "spagnole" e "veneziane” nel teatro di Baldracca (1641-1665)', Studi secenteschi, 41 (2000), 313-353, esp. p. 335.

15 On the social diversity of the spectators at the Baldracca theater, see Nicola Michelassi, 'La "Finta pazza”', p. 315: 'Baldracca non appare dunque uno stanzone malfamato condannato alla sterile ripetizione dei lazzi dell'Arte, ma un luogo di irradiamento culturale, pacificamente condiviso da tutte le fasce sociali (compresa l'aristocrazia nobiliare e i principi medicei, che vi si recavano regolarmente), dove si potevano apprezzare novità spettacolari di portata determinante'.

16 Michelassi and Vuelta García, 'La fortuna del teatro spagnolo', p. 31. 
after debating with himself over the right course of action, appears to obey the king's commands: he tells Don Gastone that he is to be exiled by the king and orchestrates the murder of the couple's son, Celio, in order to weaken Donna Violante's resistance to her unwanted royal suitor. Don Merichex goes even further than the king demanded: he takes it upon himself to invite Don Gastone and Donna Violante to a farewell dinner during which they are served their dismembered son. Finally, Don Merichex succeeds in arranging the long desired encounter between the king and Donna Violante. Only at the end of the play do the characters (and the spectators) learn that Celio is still alive and that the king spent a night with his neglected wife — not with Donna Violante. Don Merechex, therefore, only feigned his execution of the tyrant's orders and did not betray Don Gastone, his friend. In the end, Don Merechex's shrewd manipulation of appearances makes the king better understand his obligations to his people, leads to the re-establishment of order from confusion, and restores domestic and political stability.

Fausta Antonucci has identified as Il Don Gastone's possible sources three plays by Pedro Calderón de la Barca, Lope de Vega, and Tirso de Molina. ${ }^{17}$ With Calderón's Gustos y disgustos son nada más que imaginación (Pleasure and Displeasure are Nothing but Imagination, 1638), Cicognini's drama shares the motif of a king's inappropriate desire for a married noblewoman. Unlike Gustos y disgustos, however, Il Don Gastone places much more emphasis on the problematics of power, the opposition to tyranny, and the courtier's relationship to the prince. As for his other potential sources, Cicognini may have derived the motif of the faithful noblewoman's resistance to the tyrannical king from Lope de Vega's La corona merecida (The Deserved Crown, 1603) and the motif of friendship between two noblemen as well as the political meaning of their bond from Tirso de Molina's Cómo han de ser los amigos (How Friends Should Be, 1612). Antonucci goes on to suggest that II Don Gastone also recalls the early dramatic works of Guillén de Castro because of the play's gravity and its moral and political implications. She argues, therefore, that while Il Don Gastone clearly embraces sequences, situations, and plot lines taken from several Spanish Siglo de Oro comedias, the problematics structuring Cicognini's play are not present in these sources..$^{18}$ In contrast with them, in my interpretation, Cicognini gives centre stage to reflections on tyranny and thoroughly integrates discussions of politics with the play's action. Il Don Gastone thus resonates with the political

\footnotetext{
17 Fausta Antonucci, 'Spunti tematici e rielaborazione di modelli spagnoli nel Don Gastone di Moncada di Giacinto Andrea Cicognini', in Profeti (ed.), Tradurre, riscrivere, mettere in scena, pp. 65-84. 
themes of its age: the theatricality of royal power, the overriding importance of appearances at court, the courtier's relationship to the prince and to other courtiers, the discourse on civility, and the art of dissimulation.

There is, in fact, good reason to believe that Cicognini's decision to modify the plot lines of the plays on which he drew so as to emphasize the political significance of his narrative was neither random nor casual. The political resonance of Il Don Gastone is heightened by its tragicomic form ${ }^{19}$ — which, in an Italian context, was itself politically charged if not politically dangerous, as it offered an alternative to existing systems of government. ${ }^{20}$ Indeed, Giambattista Guarini, who set a foundational precedent with the publication of Il pastor fido (The Faithful Shepherd, 1590), defended the genre of pastoral tragicomedy, with its controversial social mingling of the upper and lower classes, by comparing it to the mixed political form of the republic, asking rhetorically: 'Why cannot poetry make the mixture, if politics can do it??' ${ }^{21}$ By deploying the tragicomic form, Cicognini, as we will see, was thus deliberately elaborating a new aesthetics for a tragic genre that was suited to a mixed audience-a genuine cross-section of the population - that could (and did) identify in complex, bespoke ways with the social and political conflicts portrayed upon the stage. ${ }^{22}$

19 The play was defined as an opera spagnola in the Laurenziano manuscript, as an opera tragicomica in the 1658 editions of Rome (published by Angelo Bernabò dal Verme with the title Il D. Gastone, overo la più costante tra le maritate. Opera tragicomica) and Perugia (published by Sebastiano Zecchini with the title Il gran tradimento contra la più costante delle maritate, overo L'amico traditor fedele: Opera tragicomica), and as an opera scenica e morale in the $165^{8}$ Venetian edition (published by Nicolò Pezzana with the title $I l$ Don Gastone di Moncada, Opera scenica e morale). On the complex textual tradition and printing history of the play, see Antonucci, 'Spunti tematici', pp. 67-68.

20 I owe this point to James J. Yoch's discussion of the political message in Italian tragicomedies. See his 'The Renaissance Dramatization of Temperance: The Italian Revival of Tragicomedy and the Faithful Shepherdess', in Nancy Klein Maguire (ed.), Renaissance Tragicomedy: Explorations in Genre and Politics (New York: AMs Press, 1987), pp. 115-138. See also Marvin T. Herrick's still valuable Tragicomedy: Its Origin and Development in Italy, France, and England (Urbana: University of Illinois Press, 1962).

21 Giambattista Guarini, Compendio della poesia tragicomica (The Compendium of Tragicomic Poetry, 1601), in Allan H. Gilbert (ed. and transl.), Literary Criticism: Plato to Dryden (Detroit: Wayne State University Press, 1967), pp. 505-533, esp. p. 511.

22 It is worth noting that the Arcadian letterato Giovanni Maria Crescimbeni claimed in 1700 that Cicognini's creation of a rich impasto of tragedy and comedy was emblematic of the decline of Italian theater: '[...] Giacinto Andrea Cicognini intorno alla metà di quel secolo con più felice ardimento introdusse i Drammi con suo Giasone, il quale per vero dire è il primo, e il più perfetto Dramma, che si truovi; e con esso portò l'esterminio dell'Istrionica, 
To return for a moment to Cicognini's dramaturgical models, it should also be pointed out that the sententious discourses of the characters, the violent coups de théâtre, and the vivid horrors of the banquet scene-in which Gastone and Violante are served the blood and heart of their apparently murdered son-recalls some aspects of Senecan tragedy, as revived by Giovan Battista Giraldi. ${ }^{23}$ Particular prominence given to suspense, the inganno a lieto fine, and the play's untroubled resolution all echo the innovative form of the tragedia di lieto fine created by Giraldi, who justified tragic plots with happy endings, claiming that events 'should come about in such a way that the spectators are suspended between terror and pity until the end, which, with a happy outcome, should leave everyone consoled'. ${ }^{24}$ Though Cicognini's play is also tragicomic, it does not conform exactly to Giraldi's mixed-mood form of tragedy (which depicts the virtuous characters' escape from their tragic fate as well as the evil characters' downfall), since Il Don Gastone ends happily for the villain as well as for the protagonists.

In sum, what makes Cicognini's play worthy of our attention is its status as a product of intense cultural exchange and as an assemblage of different sources, genres, and dramatic models ranging from Spanish comedias and the native Italian tradition of commedia dell'arte to Giraldi's tragedies with happy endings. In fact, it is the very heterogeneity of Cicognini's source material that enables

per conseguenza della ver, e buona Comica, e della Tragica stessa; imperciocchè per maggiormente lusingare colla novità lo svogliato gusto degli spettatori, nauseati ugualmente la vista delle cose Comiche, e la gravità delle Tragiche, l'inventor de' Drammi unì l'una e l'altra in essi, mettendo pratica con mostruosità non pià udita tra Re, ed Eroi, ed altri illustri Personaggi, e Buffoni, e Servi, e vilissimi uomini. Questo guazzabuglio di personaggi fu cagione del total guastamento delle regole Poetiche, le quali andarono di tal maniera in disuso, che nò meno si riguardò più alla locuzione [...].' Cf. La bellezza della volgar poesia spiegata in otto dialoghi (Rome: Buagni, 1700), Dialogo VI, pp. 140-142.

23 Giovan Battista Giraldi, Discorso intorno al comporre delle commedie e delle tragedie (Discourse on the Composition of Comedies and Tragedies, 1543), in id., Scritti critici, ed. Camillo Guerrieri Crocetti (Milan: Marzorati, 1973), p. 184: 'E ancora che Seneca tra i Latini non abbia mai posta mano alle tragedie di fin felice, ma solo si sia dato alle meste con tanta eccellenza che quasi in tutte le tragedie egli avanzò (per quanto a me ne paia) nella prudenza, nella gravità, nel decoro, nella maestà, nelle sentenze, tutti i Greci che scrissero mai [...]. Nondimeno noi, n'abbiamo composta alcuna a questa immagine, come l'Altile, la Selene, gli Antivalomeni e le altre, solo per servire agli spettatori, e farle riuscire più grate in iscena, e conformarmi più con l'uso dei nostri tempi'.

24 Ibid., p. 184: 'Si debbono nondimeno far nascere gli avvenimenti di queste men fiere tragedie in guisa che gli spettatori tra l'orrore e la compassione stiano sospesi insino al fine, il qual poscia riuscendo allegro gli lasci tutti consolati'. 
and results in his ambivalent portrayal of both sovereignty and tyranny. At the same time as he was influenced by them, however, the playwright seems to have drawn on this wide range of sources in order to unsettle and, indeed, depart radically from them. What is striking about Il Don Gastone is that it is critical throughout in its representation of royal sovereignty, and yet its outcome is entirely forgiving of the villainous king. We might easily expect otherwise, since Pietro d'Aragona is characterised as a tyrant right from the outset. In Act I, scene 1 - even before the audience is granted their first glimpse of the king — we hear several comments, mostly negative, about his character. The first of these is by Scappino, a servant of Don Gastone ${ }^{25}$ who explains to another secondary character that although he has never seen the king in person, it is better to stay away from him:

Non hò mai visto in viso il Rè d'Aragona perche subito, che andai alla Corte con D. Gastone m'amalai [...]; mà credimi pure, che lo star lontano da lui, è un star lontano dal Diavolo, perche di Rè non hà se non il nome, l'opere son da bestia, e da Tiranno.

I.1

(I have never seen the King of Aragon in person because as soon as I went to court with D. Gastone I fell ill [...]. But believe you me: to stay away from him is to stay away from the Devil, because he has nothing of a King about him but the title-his deeds are those of a beast and of a Tyrant.)

Later in Act I, Don Gastone (reproaching Scappino for not having recognised Don Merichex as a nobleman, and thus failing to greet him properly upon his arrival) is also indirectly critical of the king's tyrannical rule: 'whence have you learned the Doctrine of Tyranny? If you were instructed in such errors at the Court of Aragon, know that my Duchy is a place where one employs only respect' ('ove imparasti la Dottrina della Tirannide? Se nella Reggia d'Aragona fosti ammaestrato in cos' fatti errori, sappi che la mia Ducea è luogo solo ove s'esercita la pietà', I.3). In the words of Donna Violante, the king's court is a 'vessel of impiety, [a] school of Hell' ('ricetto dell'empietà, scuola d'Inferno', II.17) where, according to Scappino, 'the floor is scorching and the air is pestiferous'

25 Cicognini's dramatic works and opera librettos (and seventeenth-century Venetian librettos more generally) are replete with comic, clownish, Spanish graciosos-like low-ranking characters. Their function is to play the role of side-kick to a highborn character, to support primary characters in helper roles, and (as is the case with Scappino) to predict the deeds of the hero. See Antonucci and Bianconi, 'Plotting the Myth', p. 202. 
('il pauimento scott[a], e [...] l'aria [è] contagiosa', II.16). The king of Aragon clearly stands for an absolutist monarchy gone terribly wrong: he is driven by impulse, he craves sex and enjoys the reckless pursuit of pleasure, he is indifferent to the rights of his subjects, and he is ruled by blind libido dominandi-the principal characteristic of tyrants great and small. And yet this decadent and destructive king is permitted to redeem himself completely at the end of the play, when he discovers that Don Merichex's lieto inganno has set right the king's private life and, consequently, the affairs of the state.

On the one hand, it is apparent that, far from being mere diletto, Cicognini's drama is highly politically charged. On the other hand, however, it not easy to disentangle mid-Seicento commonplaces about tyranny, bad governance, and court corruption from what I view as a specifically Cicogninian treatment of royalty. The following pages will thus attempt to interrogate this central interpretative challenge in order to show how images of Baroque kingship change when Cicognini attempts to satisfy not only the prince-as-patron and privileged playgoers, but also the collective desires of an increasingly large market and the socially diverse audience of public playhouses, academies, and religious confraternities. ${ }^{26}$

\section{The King in Love}

Given that Cicognini's attitude toward his sources was to minimise his dependence on and flaunt his departure from them - and that, as a result, comparing his play with its sources does not help us unravel the ambiguities inherent in its portrayal of sovereignty - it may be useful to consider Il Don Gastone within the specific institutional framework of the court. From Quattro- to Settecento, after all, the court was the fundamental building block of the European political system and functioned simultaneously as a platform for monarchical representation and for political negotiation. Cicognini's play is essentially a court-centred drama, but it is also a play that marks the transition from court to public the-

26 Despite Cicognini's proximity to the Medici court, the absence of references to his plays in the court diaries suggests that most of the work he produced between 1630 and 1640 was performed within the framework of the Florentine learned academies and religious confraternities (Cf. Castelli, Il teatro e la sua memoria, p. 91; Cancedda and Castelli, Per una bibliografia, pp. 54-55). Situated at the boundaries of the royal court, these assemblies were distinguished by their acceptance of participants' social diversity, their flexibility within an arena removed from royal power, and their ability to articulate new forms of sociability. 
ater. German social historian Norbert Elias's theoretical model of court society and his account of the civilizing process and the genesis of the modern, bourgeois world can thus provide a promising point of entry for the interpretation of our Florentine playwright's dramatic work.

Elias's central thesis in Über den Prozess der Zivilisation (The Civilizing Process, 1939 $)^{27}$ is that court society constitutes an important step along the path from feudal to modern state society; from society based upon physical force towards society characterized by the restriction of one's expressions of raw emotion, the control of affect, the virtue of self-discipline-indeed, precisely the dictates of early modern court etiquette. He argued that the processes of state formation and of 'courtisation' (especially as expressed in the absolutist states of seventeenth- and eighteenth-century Europe), ${ }^{28}$ the growth of administrative infrastructure, and the centralization of taxes and the use of force, reduced the level of violence between feudal lords-which in turn resulted in an increased demand for the restraint of aggressive, emotional, and sexual drives, as well as for the refinement of manners. ${ }^{29}$ Indeed, Elias maintained

27 Norbert Elias, Über den Prozess der Zivilisation: Soziogenetische und psychogenetische Untersuchungen, 2 vols. (Basel: Haus zum Falken, 1939). English translations of this text are from Norbert Elias, The Civilizing Process: Sociogenetic and Psychogenetic Investigations, ed. Eric Dunning, Johan Goudsblom, and Stephen Mennel, transl. Edmund Jephcott (Oxford: Blackwell, 2000).

28 In Elias's scenario, the civilizing process was most pronounced in the French absolutist court (The Civilizing Process, pp. 190-191, 205). On the applicability of Elias's model to the Italian Baroque court, see Marcello Fantoni, La corte del granduca: Forma e simboli del potere mediceo fra Cinque e Seicento (Rome: Bulzoni, 1994), p. 131: 'Quanto è rilevato per Firenze contraddice l'ipotesi che il Re Sole sia stato il primo sovrano a fare del cerimoniale uno strumento di potere. Nonostante che dalla fine del XVII secolo Versailles assurga a modello europeo, quello descritto da Elias non può quindi definirsi un fenomeno storicamente originale: i codici comportamentali che improntano la società di corte si elaborano altrove, ed in un periodo precedente.' See also Jon R. Snyder, Dissimulation and the Culture of Secrecy in Early Modern Europe (Berkeley: University of California Press, 2009), p. 69: 'The courts of Europe, which grew in power and number during the early modern period with the weakening of feudalism and rise of absolutism, drew extensively on the Italian model at first, only subsequently to surpass it, a process culminating at Versailles under Louis XIV'.

29 According to Elias's paradigm, it is with the arrival of the absolutist court, which took on the 'monopoly organization of physical violence', that '[...] individuals learn to control themselves more steadily; they are now less a prisoner of their passions than before. But $[\ldots]$ they are much more restricted in their conduct, in their chances of directly satisfying their drives and passions. Life becomes in a sense less dangerous, but also less emotional or pleasurable, at least as far as the direct release of pleasure is concerned [...]. Physical 
that manuals on the education of princes and manners books - which he saw as catalysts of the 'civilizing process' - imposed increasingly severe standards of control over impulse and fashioned individuals who would fit within the structures of society by instilling in them 'a compulsion to check one's own behavior.' ${ }^{30}$ Elias's observation can be confirmed by (among countless other examples) a brilliant Baroque moralist, Baltasar Gracián, who claimed in his Oráculo manual y arte de prudencia (The Art of Worldly Wisdom, 1647) that 'no mastery is greater than mastering yourself and your own passions: it is a triumph of the will'. He also pointed out that 'if one is master of oneself, one will then be the master of others'. ${ }^{31}$ It is Elias's contention that the management and control of emotion (Affektbeherrschung) and the ability to conceal one's true feelings thus functioned simultaneously as an expression and confirmation of differences in status and power. ${ }^{32}$ In other words, the absolutist court (the setting in which, according to Elias's scenario, the transformation of the individual's emotional life was the most profound) required that its members uncouple the outward display of their feelings from their inner emotional state.

Personal interactions within court society were thus characterized by the norms of 'court rationality' - that is by a balance 'between short-term desires and emotional needs, and the longer-term consequences of human action', ${ }^{33}$ What Elias's landmark analysis of the historical development of self-surveillance makes clear is that the aristocratic court was marked by an almost com-

clashes, wars and feuds diminish [...] But at the same time the battlefield is, in a sense, moved within. Part of the tensions and passions that were earlier directly released in the struggle of man and man, must now be worked out within the human being. [...] [A]n individualized pattern of near-automatic habits is established and consolidated, a specific "super-ego", which endeavours to control, transform or suppress his or her feelings in keeping with the social structure'. Elias, The Civilizing Process, pp. 374-375.

$30 \quad$ Ibid., p. 70.

31 Quoted in Snyder, Dissimulation and the Culture of Secrecy, p. 43.

32 Elias elaborates on this argument in Die höfische Gesellschaft: Untersuchungen zur Soziologie des Königtums und der höfischen Aristokratie: Mit einer Einleitung: Soziologie und Geschichtswissenschaft (Berlin: Luchterhand, 1969). English translations of this text are from id., The Court Society, transl. Edmund Jephcott (New York: Pantheon, 1983): '[...] affective outbursts are difficult to control and calculate. They reveal the true feelings of the person concerned to a degree that, because not calculated, can be damaging; they hand over trump cards to rivals for favour and prestige. Above all, they are a sign of weakness; and that is the position the court person fears most of all. In this way the competition of court life enforces a curbing of the affects in favour of calculated and finely shaded behaviour in dealing with people', p. 111.

Robert van Krieken, Norbert Elias (London: Routledge, 1998), p. 87. 
plete absence of the distinction between public and private life, since one's private feelings came to be turned to the profit and advantage of one's public life.

Elias's hugely influential study provides a viable framework employing which we might be able to offer a preliminary explanation as to why the king in Cicognini's play is characterised as a tyrant. Building on Elias's insight into the courtly bonds closely connecting social and power relations, on the one hand, and interpersonal interactions between individuals with distinct personalities and dispositions, on the other, it is possible to suggest that Pietro d'Aragona is defined as a tyrant because he is ruled by unbridled emotion and the reckless pursuit of pleasure. Indeed, in describing his feelings after encountering Donna Violante for the first time, the king demonstrates clearly that, far from being motivated by the norms of 'court rationality', he is ruled by passion and self-interest:

Venni, viddi, e persi, venni à far preda, e fui predato, viddi quella beltade, che in un punto m'accese, arse, \& incenerì, persi, ò Cielo, persi il core, è potente un Rè, dà la vita, e la toglie, mà più potente è la bellezza, che toglie la vita sì, mà per miracolo d'amore la può ridonnare; son morto, ò miei fidi, tutti gli Scettri, tutte le Monarchie non mi possono ravvivare, mà la beltà di colei è l'ultimo rimedio all'amoroso mio male.

I.10

(I came, I saw, and I was conquered; I came to be a predator and was preyed upon; I saw that beauty that, in an instant, inflamed, burned, and incinerated me; I lost—Oh Heaven!- - I lost my heart! A King is powerful, he gives life and he takes it, but yet more powerful is beauty that, yes, takes life, but because of the miracle of love can also give back life. I am dead, oh my faithful subjects! Neither all the Sceptres nor all the Kingdoms can revive me-naught but her beauty is the final cure for my love-suffering.)

It is thus his neglect of the core principle of the interdependence of social structures and human interactions, as well as his willingness to seek base pleasure at the expense of his courtiers' honour, that mark Pietro as a despot. This is made especially evident when we note that the king uses words most often confined to the political sphere and to war (his 'venni, viddi, e persi, venni à far preda' explicitly recalls Caesar's 'veni, vidi, vici'), relocating them within the sphere of private emotion. Indeed, the king's claim that he alone has the right to possess a woman who, in fact, belongs to another man ('only I am permitted to desire her and to pursue her, because only an Eagle can look 
straight at the Sun'; 'à me solo è lecito il desiderarla, e conseguirla, perche lice all'Aquila sola fissarsi al Sole', I.10), reveals that he is unable to suppress his own self-interest for the greater good of the community and that he prioritises his individual pleasure above the interests of his subjects. ${ }^{34}$ The process of pursuit reveals the dangerously seductive power a prince has, namely the power to follow his passions without fear of opposition or sanction:

Sono il Rè, ò son l'ombra? Son Vassallo, ò Signore? Più dunque può l'ostinazione d'una femina, che la mia autorità? Don Merichex, già che il sangue del figlio ucciso non fu bastante à piegare l'animo di Donna Violante, adoprisi pur la violenza, così felicitando me se stesso in Amore, farò anco conoscere à lei che un Rè è Padrone della vita, dell'honore, e dell'arbitrio ancora.

III.8

(Am I King or shadow? Am I Vassal or Lord? Is the stubbornness of a woman more potent than my authority? Don Merichex, given that the blood of her murdered son was not enough to subdue the soul of Donna Violante, let us resort to further violence. In this way, I will make myself happy in Love and I will also make her learn that a King is the Master of life, of honour, and even of will.)

If, to continue to employ Elias's sociological perspective, court society was based on 'courtly rationality' as well as on the absence of a distinction between private and public life, it is reasonable to suggest that Cicognini's king is portrayed as a tyrant precisely because he allows his private feelings to overwhelm his public role: the sovereign's uncontrolled, undisciplined private body here takes centre stage, illustrating by analogy the ineptness of a body politic under tyrannical control.

\section{The King's Failed Performance}

At this point, it will be helpful to make use of Elias's account of the rationalization of human conduct (which he places in the category of the 'civilizing pro-

34 From this point of view, the queen's accusation of her husband is also revealing: 'I tuoi gusti hanno hauuto sempre per fine il tuo sfrenato piacere, il tormento della moglie, la vergogna d'altrui', III.17. 
cess') alongside his theoretical model of early modern European courts elaborated some years earlier in Die höfische Gesellschaft (The Court Society, written 1933; published 1969). ${ }^{35}$ Elias argued that the growth of civilization and the establishment of the court as a socio-political configuration did not straightforwardly cause domestic pacification among the élite. Instead, it transformed social, economic, and political confrontations that had previously been won or lost by means of brute force into symbolic struggles in which both weapons and spoils were replaced by political acts. This new kind of representation meant that political gains and losses came simultaneously to be substitutions for and external manifestations of violence. In contrast to bourgeois-capitalist societies (where the exercise of power revolves around the acquisition of economic capital), in early modern royal courts the exercise of power required the acquisition of symbolic capital, namely status and prestige. ${ }^{36}$ Its members were therefore engaged in continuous small-scale competitive maneuvering for social advantage, power, and prestige in their efforts to secure or protect their status. This meant that king and courtiers were interdependent, as each used the other to reaffirm his (or her) position within a strict hierarchical order. Court ceremonies and etiquette were the vehicles used for expressing this interdependence: the king employed them as a means of emphasizing his unique position and his social distance from his courtiers; the courtiers employed them to display their own status within the hierarchical order of the court. As Robert van Krieken, commenting on Elias's model, explains, 'in court society, individual existence and identity were profoundly representational-they consisted of how one exhibited one's position and status to everyone else, and this process of exhibition and performance was highly competitive and constantly fluctuating. ${ }^{37}$ In other words, the successful conduct of courtly life depended upon the offstage equivalent of theatrical role-playing.

A brief comparison with Baldassare Castiglione's much translated and often reprinted Il libro del cortegiano (The Book of the Courtier, 1528), a major contributor to the 'civilizing process', illustrates the point. In the Cortegiano, Castiglione emphasizes the importance to the courtier of both appearances and making a good impression ('imprim[ere] bona opinion di sé', I.16). ${ }^{38}$ He was

35 Although The Court Society was published after The Civilizing Process (1969, in German; 1983, in English), Elias wrote it in 1933 and it thus anticipates the subsequent development of his ideas in The Civilizing Process.

${ }_{3} 6$ See Elias, The Court Society, esp. chap. IV, 'Characteristics of the court-aristocratic figuration', pp. 66-77.

37 Van Krieken, Norbert Elias, p. 88.

38 Baldassar Castiglione, Il Libro del cortegiano, ed. Giulio Carnazzi (Milan: Rizzoli, 2010), 
well aware that, by presenting his readers with an image of the perfect courtier, he was instructing them in the art of wearing different masks on different occasions ('vestirsi un'altra persona', II.19). The Cortegiano thus teaches its readers to produce and maintain an image of themselves that allows (indeed encourages) others to view it as a continuous aesthetic performance. For Castiglione, the ideal courtier was never unmasked. ${ }^{39}$

In a similar vein, the little known Italian moralist Don Pio Rossi (15811667), an aristocratic friar from Piacenza, observed in his moral lexicon Convito morale per gli etici, economici, e politici (The Moral Banquet for Ethicists, Economists and Politicians, 1639), 'most useful to he who reads, writes, teaches, governs, and Rules' ('utilissimo a chi legge, scrive, insegna, governa, Impera'), that

Questo è vn secolo d'apparenza, \& si va in maschera tutto l'anno. Pur che altri appara, non si cura d'essere da douero. [...] Pare hoggidì, che chi non sa adulare, mordere, e simulare, che chi non sa auuanzare con la dispressione, e sorgere con la sommersione altrui, vaglia nulla: sia nulla. ${ }^{40}$

(This is an age of appearances, and one wears a mask every day of the year. As long as one appears otherwise, one does not take care to be so in fact [...]. It seems that, these days, he who does not know how to flatter, snipe, and feign; he who does not know how to advance by pushing others down and to rise by means of submerging others, is worth nothing: is nothing.)

p. 71 and chap. II.26. The issue of appearances in Castiglione is explored in depth by Giulio Ferroni, ' "Sprezzatura” e simulazione', in La Corte e il 'Cortegiano', 2 vols. (Rome: Bulzoni, 1980), i: La scena del testo, ed. Carlo Ossola, pp. 119-147.

39 As Peter Burke suggests in The European Reception of Castiglione's Cortegiano (Cambridge: Polity Press, 1995), p. 31: 'courtier is itself such a role, and one which was becoming institutionalized into what Castiglione himself calls a 'profession' (II.10), in other words an art or discipline (arte e disciplina).' See also Stephen J. Greenblatt's discussion of Castiglione's The Courtier in his Sir Walter Raleigh: The Renaissance Man and his Roles (New Haven: Yale University Press, 1973), p. 38: 'Castiglione offers not a paradigm of man's freedom, but a model for the formation of an artificial identity; his courtier is an actor completely wedded to his role'.

40 Pio Rossi, Convito morale per gli etici, economici e politici (Venezia: Appresso i Guerigli, first part published 1639; second part 1657), I, chap. 'Secolo corrotto', p. 428. For more information on Rossi, see Albano Biondi, 'Il Convito di Don Pio Rossi: Società chiusa e corte ambigua', in La Corte e il 'Cortegiano', II: Un modello Europeo, ed. Adriano Prosperi, pp. 93-112. 
As Elias insists, then, the royal court developed increasingly performative and theatricalized codes of behavior that demanded mastery from its members. It can thus be defined as society of performance-a cultural and political arena of continual self-dramatization in front of one's peers and superiors. In the words of Jeroen Duindam, 'the absolute ruler and the nobility unknowingly acted out a tableau vivant of the civilizing process.' ${ }^{41}$ In this institutional configuration, where self-representation was crucial for both obtaining and retaining power, good manners, hospitality, politeness, and gift-giving became the primary gestures of that power.

If we return now to Cicognini's drama, we find a scene in the play's very first act during which the king attempts to bestow honors upon Don Gastone and Don Merichex, an action that illustrates Elias's formulations about the sociology of power relations at court. What we notice immediately, however, is that the social and commercial exchange (or gift-giving) is here reversed-it is the king's subject, Don Gastone, who gives his sovereign a considerable sum of money, not vice versa:

Conseruo in questa Ducea gran quantità d'oro, quale appresso di me infruttuoso rimane, pur troppo mi è noto, che nelle passate guerre l'Errario Regio fu in parte suiscerato dal suo tesoro, supplico la M.v. si degni per mano d'un suo seruo ricevere in tributo vn mezo million d'oro, che con douuta humiltà le presenta il più fido Vassallo della sua Corte.

I.12

(In this Duchy I guard a large amount of gold—which, in my keeping, remains without use. Unfortunately, it is known to me that during the recent wars the royal treasury was plundered of part of its wealth. I beg of Your Highness that he deign to receive, from the hand of one of his servants, a gift of half a million in gold, which with all due humility is presented to Him by the most faithful Vassal of his Court.)

It is not that subjects never gave gifts to their patrons: on the contrary, courtiers who could not offer a worthy gift to the prince would not go far. This scene, however, is revealing in that it highlights how this sovereign's gestures and actions (which, according to Elias, should mark him as a unique individual entitled to hold power over his courtiers) fail to impress his peerless status upon his subjects. If, for Elias, gift-giving confirms a power imbalance between dependent

41 Jeroen Duindam, Myths of Power: Norbert Elias and the Early European Court (Amsterdam: Amsterdam University Press, 1995), p. 166. 
and superior and, far from representing a purely economic exchange, affirms the exchangers' status, identity, and credibility, Don Gastone's gesture puts an end to the patron-dependent relationship since the king fails to perform appropriately the ritual of gift and counter-gift. Indeed, rather than produce a gift in return, the king immediately passes Don Gastone's gift to Don Merichex, clearly demonstrating that he cares little about the well-being of his impoverished state. Indeed, this scene presents us with a subject who is a better caretaker of his kingdom than is his king.

Though apparently incapable of exchanging gifts in the usual, accepted manner, the king still recognises his obligation to reciprocate Don Gastone's gift in some form; he thus attempts to confer an honorific title upon Don Gastone's son in exchange:
RÈ D. Gastone hauete figliouli?
D. GAST. Vno mio Rè, e Celio si chiama.
RÈ Di chè età?
D. GAST. Non ha ancora compito il sesto anno.
RÈ Sarà Celio nostro Cavallarizzo maggiore.
I.12
(KING Don Gastone, do you have children?
D. GAST. I have one, my king, and his name is Celio.
KING How old is he?
D. GAST. He is not yet six years old.
KING Celio will be our Senior Horse Master.)

The king's ability to reciprocate is thwarted, however, when Don Gastone explains his error in attempting to confer this honour upon a child:

D. GAST. Favore al certo non meritato, ma vaglia a dire il vero, ò Signore, come potrà così tenera mano reggere il freno di bizzaro destriero? come potrà Celio mio con fanciullesco fianco premerli il dorso? questo è honore, che a sperimentato Caualiero s'aspetta, questa è carica, che all'adolescenza, non che alla puerilità si adatti; Il zelo del buon seruitio di v.M. m’innanimisce a parlare con disinteressata libertà.

RÈ Fingo, che anco a gl'infanti non si conferiscono honori; Chi adunque giudicareste habile a tale carica?

D. GAST. Già che mi chiede V.M. dico, che giudico proportionata la carica al valore di D. Merichex. 
$\mathrm{RÈ}$

Sia adunque D. Merichex nostro Caualarizo maggiore.

I.12

(D. GAST. This is certainly an unmerited favor - it is worth telling the truth, my Lord-how will such a soft hand control the reigns of a crazed steed? How will my Celio, with his child's hips, press upon the horse's flank? This is an honour hoped for by a young Knight; this is a duty better suited to a young man than to a child. The zeal of Your Highness's good servant spurs me to speak with impartial liberty.

KING I imagine that one doesn't confer honors upon an infant. Who, therefore, would you judge able to take on this charge?

D. GAST. Since you have asked me, Your Highness, I say that I judge the task in proportion to the valor of D. Merichex.

KING D. Merichex, then, will be our Senior Horse Master.)

In Elias's scenario, as we have seen, the mechanism by which power operated in early modern court societies was representational in character and was thus heavily dependent on the extent to which others recognized it. We might therefore suggest that what makes Pietro d'Aragona a poor monarch is that he fails to represent himself properly to his subjects and to deal appropriately with his courtiers' questioning of his social superiority. The king here explicitly contributes to an all but complete reversal of power in soliciting and then deferring to Don Gastone's judgment above Pietro's own. The court in Il Don Gastone thus becomes an arena in which power is continuously renegotiatedbut not to the king's advantage, though at times by his own hand.

Elias's insights into the centrality of theatricality to the construction of successful social and political agency in the early modern court can productively be brought into conversation with recent critical assessments of early modern political thought that suggest that Baroque rulers regularly displayed their power theatrically. Stephen Orgel and Roy Strong were the first to point out that it was by means of court spectacles and public festivities that princes and the privileged élite exhibited their prominent status and attempted to reinforce their self-mythologizing via ostentatious displays, exaltations of political power, and splendid spectacle. ${ }^{42}$ Jean-Marie Apostolidès compared the role

42 Stephen Orgel, The Illusion of Power: Political Theatre in the English Renaissance (Berkeley: University of California Press, 1975); Roy Strong, Art and Power: Renaissance Festivals 14501650 (Berkeley: University of California Press, 1984). 
of the king to that of an actor in a heroic drama, in which courtiers were at once audience and secondary players, ${ }^{43}$ and Stephen Greenblatt explored the theatrical means by which English Renaissance rulers and historical figures created their 'selves'.44 Indeed, the oft-quoted response of Queen Elizabeth to a parliamentary petition for the execution of Mary, Queen of Scots ('we princes $[\ldots]$ are set on stages, in the sight and view of all the world dulie observed; the eies of manie behold our actions'), epitomizes what Greenblatt has called 'the whole theatrical apparatus of royal power' and the dependence of Elizabethan power 'upon its privileged visibility'.45 According to Louis Marin's compelling study of the semiotics of French absolutism in Le portrait du roi, the representation of sovereignty in Baroque political regimes involved the theatricalization of public action and its resulting effects. ${ }^{46}$ Even Jürgen Habermas, working within a different framework and distinguishing between the forms of publicity that set the early modern period apart from the eighteenth century, suggested in a somewhat similar vein that the exercise of sovereignty involved the public display of power before the people. Monarchs and their peerage 'represented their lordship not for but 'before' the people' ('sie [die Herrscher] repräsentieren ihre Herrschaft, statt für das Volk, 'vor' dem Volk'). ${ }^{47}$ A sovereign thus established his authority via a mode of public self-representation that rendered the invisible source of his political power visible in physical—bodily—form, a type of ceremonial representation that marks the body of the lord with what Habermas calls the mystical 'aura' of his own authority. It is worth noting that the English and French monarchies were, however, scarcely different from any other monarchy from almost any historical era in their reliance on the application of the arts of theater to the projection of kingship. ${ }^{48}$

43 Jean-Marie Apostolidès, Le roi-machine: Spectacle et politique au temps de Louis XIV (Paris: Minuit, 1981), p. 8. See also his Le Prince sacrifié: Théâtre et politique au temps de Louis XIV (Paris: Minuit, 1985).

44 Stephen J. Greenblatt, Renaissance Self-Fashioning: From More to Shakespeare (Chicago: University of Chicago Press, 1980).

45 Id., 'Invisible Bullets: Renaissance Authority and its Subversion, Henry IV and Henry v', in Jonathan Dollimore and Alan Sinfield (eds.), Political Shakespeare: New Essays in Cultural Materialism (Manchester: Manchester University Press, 1985), p. 44.

46 Louis Marin, Le portrait du roi (Paris: Minuit, 1981).

47 Jürgen Habermas, Strukturwandel der Öffentlichkeit: Untersuchungen zu einer Kategorie der bürgerlichen Gesellschaft. Mit einem Vorwort zur Neuauflage (Frankfurt a.M.: Suhrkamp, 1990). English translations of this text are from Habermas, The Structural Transformation of the Public Sphere: An Inquiry into a Category of Bourgeois Society, transl. Thomas Burger with Frederick Lawrence (repr. Cambridge, MA: MIT Press, 1989), p. 8.

48 See, for example, John Huxtable Elliott, 'Power and Propaganda in the Spain of Philip IV', 
These critical perspectives complicate Elias's picture of court society and shed light on the fact that when politics, like all the world, was a stage, Baroque princes saw themselves on a rostrum before spectators and understood themselves and their activities in terms of the theatricality of their roles. In light of these broader insights, the specific scenes in Il Don Gastone of the king's lack of self-control and his subjects' absent recognition of his authority-not to mention the numerous other critiques he receives - suggest that one of his failings is ineffective role-playing. Let us therefore see whether there are other aesthetic criteria of the performance of sovereignty that Cicognini's king of Aragon fails to satisfy.

\section{A Theater of Dissimulation}

The most influential phenomena to contribute to and reflect on the increasingly performative codes of behavior in early modern political regimes were, according to Elias, courtesy manuals and advice books for princes. If one of the cornerstones of social and power relations at court was self-control, the other governing principle-upon which contemporary manners books rather insisted and which was closely connected to both the manipulation of appearances and the theatricality of political behavior - was the art of dissimulation. Indeed, the sixteenth and seventeenth centuries have been known as 'the age of dissimulation,49 a feature of the period that figures prominently in contemporary courtesy books and in literature on politics and statecraft (perhaps because, as we have seen, politics during the same period took on a decidedly theatrical dimension). It is interesting to note that the decade of the 1640sprecisely when Cicognini's play was first performed - saw the climax of the debate over dissimulation and its correlative, simulation. ${ }^{50}$

in id., Spain and its World, 1500-1700: Selected Essays (London: Yale University Press, 1989), pp. 162-188 on how symbols were manipulated to enhance the power and majesty of Philip IV. On the Italian context, see Matteo Casini, I gesti del principe: La festa politica a Firenze e Venezia in età rinascimentale (Venice: Marsilio, 1996).

49 See Snyder, Dissimulation and the Culture of Secrecy, p. 5. See also Rosario Villari, Elogio della dissimulazione: La lotta politica nel Seicento (Rome: Laterza, 1987); Perez Zagorin, Ways of Lying: Dissimulation, Persecution, and Conformity in Early Modern Europe (Cambridge, MA: Harvard University Press, 1990).

5o Zagorin, Ways of Lying, p. 3: 'Although the term dissimulation occurs somewhat more commonly in the literature than simulation, the two are simply different sides of the same coin. [...] Dissimulatio signified dissembling, feigning, concealing, or keeping secret. Simulatio 
Of course, Niccolò Machiavelli had already argued (in the famed eighteenth chapter of Il principe (The Prince, 1513), a book which has been a vademecum for tyranny ever since) that a prerequisite for the virtuous prince was the ability to manipulate appearances. Machiavelli asked his prince to play his part with care; to lie yet to seem to tell the truth. A ruler, he argued, must be strong like a lion and clever like a fox, and a key element of this cleverness is the ability to be a 'great feigner and dissembler' ('gran simulatore e dissimulatore'). ${ }^{51} \mathrm{~A}$ politician may be successful while entirely lacking in admirable qualities, 'but it is very necessary that he seem to have them' ('ma è bene necessario parere di averle', my italics). ${ }^{52}$ Dissimulation had thus long been thought of as an inescapable component of the political world.

Many Seicento works on dissimulation extended this Machiavellian principle beyond the conduct of princes to that of other members of the body politic. What had originally been characteristic of princely conduct thus became the standard modus operandi (or, to quote Castiglione, the regula universalissima or universal rule) of other groups within the state apparatus. ${ }^{53}$ Jon Snyder has pointed out that, 'as a practice of self-censorship, dissimulation assisted those who sought not to reveal or disclose anything of their own interiority, but were at the same time intent upon not uttering any untruth to others. ${ }^{54} \mathrm{He}$ further explains that ' $[d]$ issimulation at court was a supremely self-conscious art of producing an image of oneself for others through language, gesture, and action, among other things, even if such a representation was intended to disclose little or nothing about the courtier's true intentions [...].$^{55}$ Castiglione's courtiers famously named this principle of hypocrisy-by-design, coining the neologism sprezzatura - that is, a certain cultivated nonchalance; a masking artifice that makes everything appear spontaneous and effortless. ${ }^{56}$

also meant feigning or a falsely assumed appearance, deceit, hypocrisy, pretense, or insincerity. The two words might therefore be used interchangeably, each denoting deception with the further possible connotation of lying'.

$5^{1}$ Nicolò Machiavelli, Il principe, in id., Opere, 2 vols., ed. Corrado Vivanti (Turin: EinaudiGallimard, 1997), vol. I, chap. 18, p. 166.

$52 \quad$ Ibid.

53 Castiglione's regula universalissima for court behavior consists in avoiding 'quanto più si po, e come un asperissimo e pericoloso scoglio, la affettazione; e per dire forse una nova parola, usar in ogni caso una certa sprezzatura, che nasconda l'arte, e dimostri, ciò che si fa e dice, venir fatto senza fatica e quasi senza pensarvi'. Cf. Castiglione, Cortegiano, I.26, p. 81.

54 Snyder, Dissimulation and the Culture of Secrecy, p. 6.

55 Ibid., p. 75 .

$5^{6}$ Cortegiano I.26 is an important chapter for the praise of apparent effortlessness ('certa 
But if, for Castiglione's courtiers, engagement in a kind of theatrical selfpresentation (both simulative and dissimulative) was the convention of a gracious court game, in the new historical constellation of Seicento Italy, wearing masks and disguises became an indispensable ingredient of life for other members of the political élite: courtiers, secretaries, bureaucrats, counselors, ambassadors, and spies. Indeed, Paolo Sarpi (1552-1623), a counselor to the Venetian Republic and both a practitioner and a theorist of politics, openly recommended hypocrisy, describing himself as a chameleon that takes on the color of its surroundings:

Ego eius ingenii sum, ut, velut Chamalaeon, a conversantibus mores sumam; versum, quos ab occultis, et tristibus haurio, invitus incordio: hilares et apertos sponte ac libere recipio: personam coactus fero; licet in Italia nemo sine ea esse possit. ${ }^{57}$

(My character is such that, like the Chameleon, I imitate the behavior of those amongst whom I find myself. Thus if I am amongst people who are reserved and gloomy I become, despite myself, unfriendly. I respond openly and freely to people who are cheerful and uninhibited. I am compelled to wear a mask. Perhaps there is nobody who can survive in Italy without one.)

If we read the king's behavior in Cicognini's play against the backdrop of Machiavelli's and Castiglione's recommendations to princes and courtiers as well as of Sarpi's self-portrait, another reason for Il Don Gastone's representation of the sovereign as dissolute becomes apparent: the king rejects the cardinal rule of highly theatricalized courtly etiquette, the ars simulandi et dissimulandi. In the gift-exchange scene discussed above, the king-irritated by Don Gastone's spontaneous act of generosity that is, apparently, devoid of personal ambition—claims to dissimulate:

sprezzatura', or 'sprezzata disinvoltura'). For further discussion on this point, see Frank Whigham, Ambition and Privilege: The Social Tropes of Elizabethan Courtesy Theory (Berkeley: University of California Press, 1984), pp. 93-95.

57 Paolo Sarpi, Letter to Jacques Gillot, 12 May 1609, quoted in David Wootton, Paolo Sarpi: Between Renaissance and Enlightenment (Cambridge: Cambridge University Press, 1983), p. 119. For more detailed information on Sarpi, see Filippo De Vivo, 'Paolo Sarpi and the Uses of Information in Seventeenth-Century Venice', Media History 11 (2005), 37-51. 
Superbo è D. Gastone, la sua humiltà è la superbia stessa, convien simulare. Accetto di buon grado il vostro dono, perche ne vediate gli'effetti, ecco che ne dispongo, come Padrone; dono à D. Merichex il mezo millione con altrettanto appresto.

$\mathrm{I} .12$

([Aside] D. Gastone is proud, his humility is pride itself—it is fitting to feign.

[To D. Gastone] I willingly accept your gift; so that you can see its effect, see how I dispose of it, as a Lord: I give to D. Merichex the half million with the same eagerness.)

With these words, Pietro d'Aragona openly acknowledges theatrical artifice, whereas a skilled dissimulator does exactly the opposite, announcing nothing and allowing no one to know for sure whether a mask is or is not being used. The king, in contrast, signals his own role-playing, pointedly exposing the mechanisms of theater at work and reminding the audience of the circumstances of performance. In a society in which each member is an actor who pursues strategies of covert action and theatrical deception, Cicognini's king exhibits Castiglione's disgrazia dell'affettazione, the cardinal sin of affectation. ${ }^{58}$

The king's inability to rely on his skills as a dissimulator and on his dramatic self-representation becomes even more apparent when we see not only that he does not (or cannot) properly perform his royal role, but also that he makes his subjects play his role instead. At the outset of the play, for example, when Pietro first arrives at Don Gastone's duchy, he asks his servant to pretend to be a king in order to deceive Scappino and to discover why Don Gastone had fled the court for the country. Later in the play, unable to seduce Donna Violante by threat or force, he commissions Don Merichex to arrange her seduction. During the next two acts of the play, therefore, the king increasingly becomes a mere spectator of a well-staged performance that is orchestrated almost entirely by Don Merichex.

$5^{8}$ Castiglione, Cortegiano, II.7, pp. 122-123: 'Voglio adunque che 'l nostro cortegiano in ciò che egli faccia o dice usi alcune regole universali, le quali io estimo che brevemente contengano tutto quello che a me s'appartien di dire; e per la prima e più importante fugga [...] sopra tutto l'affettazione. Appresso consideri ben che cosa è quella, che egli fa o dice, e 'l loco dove la fa, in presenzia di cui, a che tempo, la causa perché la fa, la età sua, la professione, il fine dove tende, e i mezzi che a quello condur lo possono'. 
The eclipsing of the king as a model royal figure is particularly evident when we compare him to the character of Don Merichex, a man skilled at wearing masks and at prudently simulating and dissimulating. Don Merichex is a hero with a particularly theatrical vision of reality who sees himself and others as theatrical fictions defined by outward appearances. His dramatic sense of life is immediately apparent: when introducing himself to Don Gastone for the first time, he describes his prior life as a tragedia, thus portraying himself as a selfaware performer in his own drama:

Non vorrei, ò Signore, che la miserabile historia de' miei funesti accidenti turbasse le delizie dell'anima vostra, che nel resto, il narrar la mia tragedia mi darà doppio contento, l'uno perche vi ubbidisco, e l'altro perche il raccontare i suoi travagli à Prencipe Generoso è di sollievo al tormento. I.4, my italics

(I do not wish, dear Sir, that the sad history of my woeful mishaps disturb the delights of your soul, though for the rest, telling my tragedy will give me double pleasures: one because I am obeying you, and the other because describing one's travails to a Generous Prince is to relieve one's torment.)

His words display an acute awareness of and radical conviction that Baroque man was not just similar to a character on the theatrical stage- he was in fact identical to an actor on stage and viewed both himself and the world as a theatrical fiction. ${ }^{59}$

When receiving the king's orders to exile Don Gastone and to arrange the seduction of Donna Violante, Don Merichex is torn between his loyalty to his friend and to his prince:

Oh Dio, ed a qual segno son io ridotto? ò devo mancar al giuramento dato al Rè, ò tradire nell'honore l'amico, se io voglio osseruare, come Caualiero, e forza ch'io manchi, come traditore; non posso preparare la cura alle

59 On the flourishing of the theatrum mundi topos in early modern writing and the Baroque fascination with the theatricality of the world, see Ernst Robert Curtius's foundational European Literature and the Latin Middle Ages (Princeton, NJ: Princeton University Press, 1990), pp. 138-144. See also the excellent surveys by Lynda G. Christian, Theatrum mundi: The History of an Idea (New York: Garland, 1987), pp. 150-192; Frances A. Yates, Theatre of the World (London: Routledge and Kegan Paul, 1969); Georges Forestier, Le Théâtre dans le théâtre sur la scène française du XviIe siècle (Geneva: Droz, 1981), p. 341. 
dolcezze di Sua Maestà, ch'io non fabrichi la tomba della riputatione di D. Gastone.

II.9

(Oh God, to what act am I reduced? Either I must break my oath to the King, or betray my friend's honor. If I want to keep my oath, like a Knight, I am forced to break faith, like a traitor; I cannot attend to His Majesty's pleasures unless I build a tomb for D. Gastone's reputation.)

He thus struggles to make ethical sense of the issues and to act with both justice and humanity:

O tormentato Don Merichex: in qual tenebroso laberinto ti sei ciecamente condotto? S'io penso alla promessa fatta al Rè, sento inuitarmi all'osservanza; s'io mi ricordo dell'obligationi con D. Gastone, mi sento sconsigliare, il giuramento mi sforza, il tradimento mi respinge, l'autorità Reggia mi comanda l'amicizia non lo comporta, mancar di fede al Rè non posso; machinar contro l'honore di D. Gastone non deuo, l'essere spergiuro mi spaventa, tradir l'amico mi vitupera: oh promessa, oh tradimento, ò giuramento, ò amicitia, ò Rè, ò Don Gastone, ò fierissimi tiranni dell'anima mia, così mi tormentate? così maffliggete.

I. 9

(O tormented Don Merichex! Into what shadowy labyrinth have you blindly allowed yourself to be led? If I think of the promise I made to the King, I feel compelled to keep it; if I recall my obligations to D. Gastone, I feel advised against it. The oath binds me, the betrayal repels me, the authority of the State commands me, friendship does not permit it, I cannot break faith with the King, I must not conspire against the honour of D. Gastone, becoming a liar frightens me, betraying a friend vilifies me. Oh promise, oh betrayal, either oath or friendship, either King or D. Gastone, oh haughtiest tyrants of my soul, how you torment me! How you afflict me!)

While this audience-directed, emotionally-charged soliloquy reveals the internal conflict and emotional turmoil of the character, his subsequent actions show an extraordinary mastery of self-dramatization. Indeed, his thoughts and feelings remain completely inaccessible both to other characters and to the play's spectators until the very last scene. His actions thus put into practice Pietro Bembo's advice from the second book of Castiglione's Cortegiano, which 
states that nothing should ever be said unless it has been well thought through beforehand and that one should never trust anyone, not even a dear friend, to the extent that he 'communicate without reservation all one's thoughts to him. 60

Don Merichex is a complex character who is conscious of the degree to which the inner self reflects the outer, public self in its daily interactions with one's sovereign and fellow courtiers. Indeed, he reminds himself, 'remember that, with regards to one's actions, one must think of the end result, and that breaking faith with the King has as its end the honour of a friend, and that keeping faith has as its outcome that friend's shame' ("[r]iccordati, che nelle attioni si deue pensare al fine, e che il mancar di fede al Rè hà per fine l'honor dell'amico, e che osservarui fede ha per scoppo le sue vergogne,' II.9). In addition to his status as savvy central character and his vital role as problemsolver, Don Merichex is a stage manager, a role through which his character comes to compete with that of the king, and through which the performance of an onstage courtier comes to echo and challenge the 'performance' that is state ritual. Don Merichex, in fact, is always in control of the monarch's movements on stage, as well as of the entries and exits of the other characters. Contrary to what we might expect given the title of the play, Don Merichex-not Don Gastone-is thus the true protagonist of Cicognini's drama.

Yet another aspect of theatricalization in Baroque political regimes is the dependence of princes on their audiences. Indeed, Don Pio Rossi emphasized 'living a theatrical life' ('vivere una vita da teatro') among the 'many miseries which accompany the greatness of the prince', precisely because the great were always 'in the view of a world of spectators' ('alla veduta d'un mondo di spettatori'):

La Grandezza trà le molte miserie, che l'accompagnano, ha questa non inferiore ad ogn'altra; di viuere vna vita da teatro: percioche esposti i Grandi continuamente sono alla veduta d'vn mondo di spettatori: \& ogni minimo loro portamento è specolato da tutti, con ogni più critica diligenza, come di quelli, che sono posti sopra 'l Candelliero dell'Eminenza, ò sopra la colonna delle grandezze per illustrare tutta vna casa, e tutta una Prouincia. ${ }^{61}$

(The condition of the great: among the many miseries that accompany her, the one that is inferior to no other is that of living a theatrical life, due

$60 \quad$ Castiglione, Cortegiano, II.29, p. 236.

61 Pio Rossi, Convito, II, chap. 'Grandezza Regale', p. 175. 
to which Great men are continually exposed to the glare of a world of spectators, and their most insignificant action is watched by all with the most critical diligence, like those who are placed upon the Chandelier of Eminence, or on top of the column of the great to represent a whole house, and a whole Province.)

As David Scott Kastan has observed, '[a] spectacular sovereignty works to subject its audience to - and through - the royal power on display, captivating, in several senses, its onlookers. But this theatrical strategy of what Stephen Greenblatt has called "privileged visibility" carries with it considerable risks. Significantly, it makes power contingent upon the spectators' assent [...].'62 The monarch must, in other words, continually play to his subjects, subjecting himself to their admiration and showing that he takes seriously his responsibility to represent performatively — theatrically—his unique status and peerless power as evidence of his leadership ability.

The numerous critiques of Pietro d'Aragona's rule reveal that Il Don Gastone is not merely an expression of aesthetic concern about the centrality of theatricality to the construction of successful social and political agency. Instead, what makes this king a tyrant is his inappropriate liberation from the restraints of popular opinion-he does not care about the response of his audience. Scappino (who, despite being a lower-class character demonstrates a good deal of moral wisdom) makes a revealing comparison between the king and his master (Don Gastone) that underlines the king's indifference to popular opinion:

Don Gastone è persona honorata, il Rè d'Aragona non hà altro pensiero, che compiacere à sè stesso. Don Gastone è Caualiero d'azzioni Illustri, il Rè è solo Rè di nome, ma perche pure è il Rè, e mescolando l'autorità Reggia con la Tirannide, e facendendosi vn decotto al fuoco delle opinioni del Mondo scema due terzi dell'huomo da bene, e dell'altro terzo se ne caua vn siroppo di furfante.

I.7, my italics

(Don Gastone is an honorable person; the King of Aragon has no other thought than to please himself. Don Gastone is a Knight of Illustrious Actions, the King is only King in name, but precisely because he is King and confuses the authority of the State with Tyranny, and, if he were brewing himself a herbal remedy from of the opinions of the world, he would

62 David Scott Kastan, 'Proud Majesty Made a Subject: Shakespeare and the Spectacle of Rule', Shakespeare Quarterly 37 (1986), 459-475, esp. p. 466. 
discard the two thirds coming from virtuous men and obtain his syrup from the other, good-for-nothing third.)

When Scappino, after having discovered that he had been speaking to the king in disguise, asks Pietro d'Aragona to forgive him for having spoken so improperly, the king replies that 'the great do not care about the injuries of buffoons' ('I grandi non curano l'ingiurie de buffoni', I.8). In addition to his refusal to role play according to the established rules of courtly etiquette; his inability to manipulate the visual and verbal symbols of power; and his subjects' lack of recognition of his authority, therefore, the king's chief flaw — what, in other words, makes him a tyrant in the eyes of his subjects and of the play's audience-is his indifference to his own public image and to the popular opinion of it — and, by extension, of his status and ability as a ruler. If, during the Baroque age, the theater metaphor was a governing mode of almost all forms of human behavior — social, political, and aesthetic —Cicognini's king's failing is that he forgets that theater and, in particular, the performance of politics is always dependent on its audience. The theatrical metaphor, therefore, has here ceased to describe political authority.

\section{The Dramaturgy of the Spectator}

If early modern theater was a medium for the circulation of information, ideas, and opinion formation in particular concerning political institutions and events, what conclusions can be drawn about the explicit or implied meaning(s) of Cicognini's drama for its seventeenth-century audiences? Why did its performance of sovereignty and the aesthetics of power make it appeal widely to different kinds of publics? How can we explain the interest of the eighteenth-century reading public in this court-focused play and the relatedand immense-editorial success of Il Don Gastone? One answer to these questions could be that, by exposing royal sovereignty as empty, by revealing the monarch's position as precarious, and by showing the king's subjects assuming his role, the play provides an astute illustration of the historical transition from what Jürgen Habermas termed the 'representative' public sphere (in which monarchs represented their authoritative power and unchallenged sovereignty to quiescent subjects) to the bourgeois public sphere (in which private individuals come together to confront and problematize political authority). According to Habermas, the king's subjects under absolutism were not rational and self-conscious - they were passive spectators of a political scene that was orchestrated by the monarch and subjected to the 'aura' of his God- 
given authority ${ }^{63}$ In this scenario, the swapping of roles between king and courtiers in Cicognini's play and the latters' evolution into genuine political actors might be linked to a decisive event: the emergence of a radically new kind of public.

It may be helpful at this point to rehearse some of the prominent aspects of Habermas's discussion, particularly as it relates to the model of the public sphere. In Strukturwandel der Öffentlichkeit: Untersuchungen zu einer Kategorie der bürgerlichen Gesellschaft (The Structural Transformation of the Public Sphere: An Inquiry into a Category of Bourgeois Society, 1962, a work of social and political theory that is one of the foundational texts for current debates on the public sphere), ${ }^{64}$ the German philosopher and cultural theorist provided an account of the genesis of a public sphere that embraced private citizens who engaged in rational-critical debate (offentliches Räsonnement) on the political norms of the state. In Habermas's scenario, this 'authentic' public sphere established itself in the late seventeenth and eighteenth centuries, between absolute state and bourgeois society.

Habermas's influential definition of the public sphere helps us unravel the significance of Cicognini's drama, allowing us to consider it as a sustained illustration of his account of the new public that was just beginning to articulate its distinctiveness from past audiences. Indeed, by watching onstage characters move from subjecta to reasoning individuals; from receivers of regulations to interlocutors with authority, the spectators of IlDon Gastone were compelled to experience vicariously a particular kind of identity formation. By empathically identifying with the play's dramatic heroes, who engage critically in public

63 Habermas's contention is confirmed by a brilliant aphorism of Pio Rossi, who compared the great to the actors who fill the stage, leaving commoners to watch them from the dark of the parterre: 'Vn gran torchio leua il lume à i piccioli: E le picciole candele non vagliono gran fatto à rischiarar le tenebre, se i maggiori non s'ecclissano'. Convito, I, chap. 'Grande Primate', p. 214.

64 For critical discussion of Habermas's theory of the public sphere and its impact on literary studies, see Jonathan M. Hess, Reconstituting the Body Politic:Enlightenment, Public Culture and the Invention of Aesthetic Autonomy (Detroit: Wayne State University Press, 1999); Jan Bloemendal and Arjan van Dixhoorn, 'Early Modern Literary Cultures and Public Opinion', in Jan Bloemendal, Arjan van Dixhoorn, and Elsa Strietman (eds.), Literary Cultures and Public Opinion in the Low Countries, 1450-1650 (Leiden and Boston: Brill, 2011), pp. 267-291. On the importance of theater to crafting the public sphere cf. especially Logan J. Connors, Dramatic Battles in Eighteenth-Century France: Philosophes, Anti-Philosophes, and Polemical Theatre (Oxford: Voltaire Foundation, 2012) and Jeffrey S. Ravel, The Contested Parterre: Public Theatre and French Political Culture, 1680-1791 (Ithaca, NY: Cornell University Press, 1999). 
discussions and take on the role of active political actors, audience members were invited to project their own ability to judge matters usually considered arcane mysteries of the state. Even though we must be cautious about drawing far-reaching conclusions based upon a single playwright's body of work, my analysis of Cicognini's drama and the history of Il Don Gastone's reception suggest that the play could well have exercised a shaping influence on the formation of rational and active spectatorship. Moreover, Cicognini's drama reveals that features of the 'mature' Habermasian bourgeois public sphere were anticipated well before the Enlightenment, and IlDon Gastone can therefore be considered a theatrical precursor to this societal shift. ${ }^{65}$

If, from one perspective, Cicognini's play called into being critical and active consumers of cultural products, from an alternative perspective, the play is symptomatic of how the aesthetics of power and the dramatic treatment of royalty have been fashioned with respect to the rise of this new, potentially powerful and adjudicating public, and in response to this new public's horizon of expectations. Indeed, one can read the happy ending and the final redemption of the king as the playwright's pandering to the audience's dissatisfaction with tragic conclusions. ${ }^{66}$ The redemption of the tyrant, however, also implies

65 Although Habermas located the genesis of the modern institution of 'the public' in late seventeenth- and especially eighteenth-century England and France, insisting on the geographical specificity of his claim, literary scholars and historians of cultural and political communication have found evidence of his 'public sphere' in early modernity. See Peter Lake and Steven Pincus (eds.), The Politics of the Public Sphere in Early Modern England (Manchester: Manchester University Press, 2007); Filippo De Vivo, Information and Communication in Venice: Rethinking Early Modern Politics (Oxford: Oxford University Press, 2003); Massimo Rospocher, 'Beyond the Public Sphere: A Historical Transition', in id. (ed.), Beyond the Public Sphere: Opinions, Publics, Spaces in Early Modern Europe (Bologna: Il Mulino; Berlin: Dunker \& Humblot, 2012), pp. 9-28. To the best of my knowledge, however, there are no critical studies that explore the role played by Italian theater in shaping the emergence of a critically productive spectatorship.

66 One example of the declining taste for tragic plots in the mid-sixteenth century is the influential statement of dramatist and theater theorist Angelo Ingegneri, who claimed that 'le tragedie, lasciando da canto che così poche se ne leggono che non abbiano importantissimi e inescusabili mancamenti, onde talora divengono anco irrappresentabili, sono spettacoli malinconici, alla cui vista malamente si accomoda l'occhio disioso di dilettazione'. Maria Luisa Doglio (ed.), Della poesia rappresentativa e del modo di rappresentare le favole sceniche (Modena: Panini, 1989 [1598]), p. 7. Also revealing is the scene from the fifth chapter of Giambattista Marino's Adone (1623), in which the homonymous hero falls asleep well before the end of the magnificent tragic performance that Venus stages for her lover. For a detailed analysis of this scene, see Franco Vazzoler, 'La spettacolarizzazione 
the success the characters' agency (and, by extension, that of the audience) enjoys in bringing the tyrant to justice and, ultimately, in re-negotiating rather than simply accepting the sovereign's monopoly on self-representation.

Given the centrality of reliance on the spectator for successful political action and the paramount importance assigned to the experience of a receptive subject in Il Don Gastone, it is furthermore possible to locate in Cicognini's theater the emergence of a dramatic aesthetic that is attentive to public response. My analysis shows that this kind of aesthetics-one that is typically associated with eighteenth-century dramatic poetics ${ }^{67}$-in fact emerged precisely at the moment of transition from court theater to public playhouse. Of course, there have already been numerous attempts to emphasise the centrality of the spectator even before this moment, ${ }^{68}$ but it seems that only under the pen of a 'transitional' playwright like Cicognini does the aesthetic start to take shape in a practical way on stage.

Ultimately, the interpretation of Il Don Gastone undertaken in these pages reveals that Cicognini's wide appeal to different kinds of audiences-or publics - and his fame well into the eighteenth century was due only in part to his ability to 'tempt with novelties the listless taste of his spectators' ('lusin-

del mito fra manierismo e barocco sulle scene italiane', in Valentina Nider (ed.), Teatri del Mediterraneo. Riscritture e ricodificazioni fra '5oo e '6oo (Trento: Università degli Studi di Trento, 2004), pp. 75-87. On Cinquecento tragedy see the excellent essay by Antonella Calzavara, 'L"amor soverchio" e lo "sfrenato sdegno": Rassegna di testi e studi sulla tragedia italiana del Cinquecento (con un'appendice secentesca) (1970-1993)', Lettere italiane 46 (1994), 642-676.

67 See, for example, Hans Robert Jauss, 'La teoria della ricezione: Identificazione retrospettiva dei suoi antecedenti storici', in Robert C. Holub (ed.), Teoria della ricezione (Torino: Einaudi, 1989), pp. 3-26. See also my 'Il pubblico teatrale nel Genio buono e il genio cattivo di Carlo Goldoni', Italian Studies 70 (2015), 93-117.

68 Theories that stressed the necessity of providing satisfaction to the audience were postulated in an Italian context by Giambattista Guarini, Giraldi Cinthio, Angelo Ingegneri, and Leone de' Sommi in particular. Anna Tedesco has recently linked Cicognini's dramatic aesthetics (which emphasises keeping the public pleased and entertained) to the shaping influence of Lope de Vega's treatise El Arte nuevo de facer commedias en este tiempo (The New Art of Writing Plays in This Age, 1609, first printed in Italy in 1611), which oriented Italian playwrights towards a new kind of dramaturgy that recommended against the Aristotelian rules in favour of a more public-oriented paradigm. See her " "Capriccio", "Comando", "Gusto del pubblico" e "Genio del luogo" nelle premesse ai libretti per musica a metà del Seicento', in Giulia Poggi and Maria Grazia Profeti (eds.), Norme per lo spettacolo, norme per lo spettatore. Teoria e prassi del teatro intorno all'Arte Nuevo": Atti del seminario internazionale, Firenze, 19-24 ottobre 2009 (Florence: Alinea, 2001), pp. 345-358. 
gare colla novità lo svogliato gusto degli spettatori' $)^{69}$ and to his play's dramatic effectiveness, moral resonance, and treatment of sovereignty — one that, unusually, both critiques and affirms the current political regime. Instead, the overriding reason for Il Don Gastone's success and the principal cause of its adaptability to different theatrical contexts lies in the fact that the play is a true site of public making: Cicognini's aim was explicitly political and was designed to compel the audience to recognise its own centrality in social, theatrical, and political domains alike, and to raise consciousness among the public that it is, itself, the ultimate repository of power.

\section{Further Reading}

Antonucci, Fausta, 'Spunti tematici e rielaborazione di modelli spagnoli nel Don Gastone di Moncada di Giacinto Andrea Cicognini', in Maria Grazia Profeti (ed.), Tradurre, riscrivere, mettere in scena (Florence: Alinea, 1996), pp. 65-84

Cancedda, Flavia, and Silvia Castelli, Per una bibliografia di Giacinto Andrea Cicognini: Successo teatrale e fortuna editoriale di un drammaturgo del Seicento (Florence: Alinea, 2001)

Calzavara, Antonella. 'L"amor soverchio" e lo "sfrenato sdegno": Rassegna di testi e studi sulla tragedia italiana del Cinquecento (con un'appendice secentesca) (1970-1993)', Lettere italiane 46 (1994), 642-676

Doglio, Federico, 'La tragedia barocca', in id., Il teatro tragico italiano: Storia e testi del teatro tragico in Italia (Parma: Guanda, 1960), pp. LXXIX-CLXIV

Greenblatt, Stephen J., Renaissance Self-Fashioning: From More to Shakespeare (Chicago: University of Chicago Press, 1980)

Sberlati, Francesco, La ragione barocca: Politica e letteratura nell'Italia del Seicento (Milano: Bruno Mondadori, 2006)

Snyder, Jon R., Dissimulation and the Culture of Secrecy in Early Modern Europe (Berkeley: University of California Press, 2009)

Zanlonghi, Giovanna, 'La tragedia fra ludus e festa: Rassegna dei nodi problematici delle teoriche secentesche sulla tragedia in Italia', Comunicazioni sociali 15 (1993), $157-240$

69 Crescimbeni, La bellezza della volgar poesia, p. 142. 